\title{
Cellular Localization of the $5-\mathrm{HT}_{1 \mathrm{~A}}$ Receptor in Primate Brain Neurons and Glial Cells
}

\author{
Efrain C. Azmitia, Patrick J. Gannon, Nancy M. Kheck, and Patricia M. Whitaker-Azmitia
}

Activation of $5 \mathrm{HT}_{1 \mathrm{~A}}$ receptors produces many different physiologic responses, which may be due to their localization on diverse cells in the brain. A $5-H T_{1 A}$ receptor antipeptide (aa170-186) antibody was produced that showed both high titer for peptide binding and immunocytochemical staining. Studies performed in perfusion-fixed brain tissue showed immunoreactive neurons, glial, and ependymal cells in the rat, mouse, cat, and monkey. Results from our studies of Macaca fascicularis brains are presented. We obseroed two main neuronal labeling patterns in the primate brain: (1) A general, diffuse somatodendritic distribution of 5- $\mathrm{HT}_{1 \mathrm{~A}}$ receptor immunoreactivity is seen in the raphe nuclei where the dendritic shaft, its branches and spines, and the entire perikaryon are immunolabeled. This pattern is also observed in the nucleus locus coeruleus, in scattered large brainstem reticular neurons, and in dentate gyrus hilar interneurons. (2) A discrete localization of 5-HT 1 receptor immunoreactivity on the initial axon segment (axon hillock) is noted in pyramidal neurons of layer III and $V$ of cerebral cortex, Cornu Ammonus (1-4) of the hippocampus, and in most brainstem and cervical spinal cord motoneurons. In addition to neuronal labeling, $5-\mathrm{HT}_{1 \mathrm{~A}}$ receptor immunoreactivity is seen in the cell body and processes of astrocytes, and other nonneuronal cells. This pattern is particularly evident in the white matter of cerebral cortex and spinal cord, the pontine nuclei, the brainstem tectum, and the hilus of the dentate gyrus. The clinical implications of 5-HT 1 cellular localization are briefly discussed.

[Neuropsychopharmacology 14:35-46, 1996]
KEY WORDS: Axon hillock; Immunocytochemistry; Monkey; Cerebral cortex; Autoreceptor; Astrocytes; Dorsal raphe nucleus; Locus coeruleus; Hippocampus; Dentate gyrus

$5-\mathrm{HT}_{1 \mathrm{~A}}$ receptor agonists can elicit a wide range of behavioral, electrophysiologic, biochemical, and clinical responses despite the similarity in their pharmacologic profile (Zifa and Fillion 1992). A role for 5- $\mathrm{HT}_{1 \mathrm{~A}}$ receptors has been implicated in behaviors such as aggression, sexual activity, sleep, memory and learning, ho-

From the Department of Biology (ECA, NMK), New York University, New York, New York; Department of Otolaryngology (PJG), Mt. Sinai School of Medicine, New York, New York; and the Department of Psychiatry (PMW-A), State University of New York, Stony Brook, New York.

Address correspondence to: Efrain C. Azmitia, Department of Biology, New York University, 1009 Main Building, 100 Washington Square East, New York, NY 10003-6688.

Received April 8, 1994; revised February 14, 1995; accepted March 28,1995 . meostatic mechanisms (such as hormonal secretion, thermal regulation, blood pressure, and feeding), motor activity, and clinical disorders (e.g., depression, autism, anxiety, obsessive-compulsive behavior, anorexia nervosa, schizophrenia, and Alzheimer's disease) (see Zifa and Fillion 1992; Whitaker-Azmitia and Peroutka 1990). Furthermore, human $5-\mathrm{HT}_{1 \mathrm{~A}}$ receptor levels peak early during development, suggesting that they may also subserve functions in the developing brain (Bar-Peled et al. 1991).

$5-\mathrm{HT}_{1 \mathrm{~A}}$ receptor binding sites in rat brain have been previously mapped using the selective $5-\mathrm{HT}_{1 \mathrm{~A}}$ agonist, ${ }^{3} \mathrm{H}-8-\mathrm{OH}-\mathrm{DPAT}$ (Palacois et al. 1987). These studies have demonstrated the presence of high affinity $5-\mathrm{HT}_{1 \mathrm{~A}}$ receptor binding sites in high levels in hippocampus, cerebral cortex, and brainstem. The limitations of these studies are that they reveal only active binding sites rather than the receptor protein itself, and they have limited resolution at the cellular level. We have there- 
fore chosen to use the technology of an antipeptide antibody to localize the $5-\mathrm{HT}_{1 \mathrm{~A}}$ receptor protein in the brain and spinal cord.

In this study we report on the pattern of $5-\mathrm{HT}_{1 \mathrm{~A}}$ receptor immunoreactivity (IR) obtained with S1A-170 antibody in primate brain. The amino acid sequence 170-186 shows complete homology between the human and rat sequence, and provides a comparable pattern of $5-\mathrm{HT}_{1 \mathrm{~A}}$ receptor-IR in both species. By contrast, the third IC loop, which comprises the G protein binding site, shows considerable species differences (Albert et al. 1990; Kobilka et al. 1987). Our other S1A-258 antibody directed against this region labels the same neuronal populations as the S1A-170; however, the pattern of immunoreactivity differs in terms of cellular localization. Previous studies have reported that differential immunolabeling occurs with antipeptide antibodies directed against the various epitopes of the same protein. For example, antipeptide antibodies against the third IC loop of the $\beta$-adrenergic receptor label neuronal perikarya and dendrites but not astrocytes (Aoki and Pickel 1990). In direct contrast, an antipeptide antibody directed against the $\mathrm{C}$-terminal cytoplasmic tail of the $\alpha$-adrenergic receptor recognizes neither neuronal cell bodies nor dendrites, but does label brainstem astrocytes in the adult rat (Aoki 1992). Polyclonal antibodies recognizing the full molecule label both dendrites and astrocytic plasma membranes (Aoki et al. 1987). Furthermore, antipeptide antibodies against the $\mathrm{N}$-terminus and $\mathrm{C}$-terminus regions of the tryptophan hydroxylase molecule show the same band patterns on SDS-PAGE gels, but specific immunocytochemical labeling is only seen with the N-terminus antibody (Azmitia et al. 1992).

We report here that $5-\mathrm{HT}_{1 \mathrm{~A}}$ receptors labeled with the S1A-170 antipeptide antibody are located on many cell types (neuronal, glial, tanocytes, epithelial, endothelial, and ependymal). In neurons, the general labeling of the entire cell body and its main processes is observed in most large neurons in the brainstem raphe nuclei and locus coeruleus. In addition, a general somatodendritic pattern is seen in large multipolar neurons of the pontine reticular formation and in the hilus of the dentate gyrus. The more restricted labeling of the initial axon segment (axon-hillock pattern) is seen in pyramidal neurons of the hippocampus and cortex, and in brainstem motoneurons. A general cellular labeling pattern is also seen in a number of nonneuronal cells including radial glia, astrocytes, tanocytes, ependymal cells, and occasionally endothelial cells.

\section{MATERIALS AND METHODS}

\section{Peptide Sequences}

Three unique sequences of the $5-\mathrm{HT}_{1 \mathrm{~A}}$ receptor protein were selected based on their lack of homology with other known receptors and proteins listed in the Protein Sequence databank and the European Molecular Biology Library. Other considered criteria were hydropathicity (Hopp and Wood 1981), two-dimensional protein structure (Chou and Fasman 1978), amino-acid length, and position of asparagine, serine, threonine, and cysteine (Azmitia et al. 1992). The peptides synthesized were S1A-2-27 (N-terminus); S1A-170-186 (second extracellular (2nd EC) loop) and S1A-258-274 (third intracellular (third IC) loop). S1A-170 and S1A-258 were conjugated to KLH and used to generate polyclonal antibodies in the rabbit, whereas peptide S1A-2-27 was conjugated to BSA and a polyclonal antibody was raised in the rat. Western analysis has shown that all three antibodies can label the same protein bands in $10 \%$ SDS-PAGE gels using neonatal rat brain homogeneate (Anthony et al. 1995). The pattern of $5-\mathrm{HT}_{1 \mathrm{~A}}$ receptor-IR in neurons and glial cells in rat brain with S1A-170 antibody was similar to that seen with the antipeptide antibody against the third IC loop (sequence 242-267) synthesized by Raymond et al. (1989, 1993). Another high-affinity antipeptide antibody directed against the second EC loop has also recently been reported (Verdot et al. 1994).

\section{Antibody Preparation}

The peptide corresponding to sequence 170-186 amino acid from the published sequence (Alberts et al. 1990) was coupled to keyhole limpet hemocyanin (KLH: Sigma) via maleimidobenzoyl-N-hydroxysuccinimide (Pierce Chemical Co., Rockford, IL) as described previously (Azmitia et al. 1992) and injected subcutaneously in adult female New Zealand white rabbits. The S1A170 and the S1A-258 antipeptide antibodies label identical bands in $10 \%$ SDS-PAGE gels. Both antibodies labeled a major band of approximately 64,000 daltons in immunoblots from the rat hippocampus and midbrain, and produced a positive serum antibody titer determined by radioimmunoassay against the synthetic peptide fragment up to dilutions of 1/50,000 (Azmitia et al. 1992). The preimmune serum shows no specific labeling, and preabsorption of the antibody with the antigen-peptide blocked the specific pattern of immunoreactivity observed in brain and spinal cord sections. The antigen peptide was serially diluted from $750 \mathrm{mg} / \mathrm{ml}$ to $0.075 \mathrm{mg} / \mathrm{ml}$ with affinity purified S1A-170 antibody $(1 / 6000)$ and mixed for 4 to 6 hours under constant agitation prior to incubation of tissue slices (Kheck et al. 1995). No specific staining in tissue slices above background labeling was detected with the preimmune serum and a gradual blockade was seen with the serially diluted preabsorbed serum (total blocking occurred at $7.5 \mathrm{mg} / \mathrm{ml}$ ).

Three monkeys (Macaca fascicularis, two males, one female, 2.5 to $3.3 \mathrm{~kg}$ ) were transcardially perfused with 
$4 \%$ paraformaldehyde and $0.5 \% \mathrm{MgSO}_{4}$ in $0.1 \mathrm{~mol} / \mathrm{L}$ phosphate buffer ( $\mathrm{pH} \mathrm{7.4)}$ at $4^{\circ} \mathrm{C}$ with a total volume of 3 liters. Brain regions were postfixed in the same solution at $5^{\circ} \mathrm{C}$ for 4 to 6 hours, rinsed in phosphate buffer and processed for immunocytochemistry. Thirty-micrometer sections of the hippocampus, cerebral cortex and brainstem were cut on a Vibratome (Oxford) or freezing stage microtome.

Primary antiserum and secondary anti-IgG sera (Vector Labs) were diluted in $0.1 \mathrm{~mol} / \mathrm{L}$ phosphate buffered $(\mathrm{pH} 7.4)$ saline $(0.85 \%)$ containing $0.5 \%$ BSA and $0.1 \%$ Triton X-100. Sections were incubated for 48 to 72 hours at $5^{\circ} \mathrm{C}$ on a rotator in antipeptide antisera $(1 / 1,000$ $1 / 4,500$ ) and then processed with the avidin-biotin substrate elite $\mathrm{ABC}$-kit (Vector Labs). The reaction was run for 10 minutes at $5^{\circ} \mathrm{C}$ in $0.025 \%$ 3,3-diaminobenzidine containing $0.2 \%$ nickel ammonium sulfate in $0.1 \mathrm{~mol} / \mathrm{L}$ Tris-buffered ( $\mathrm{pH}$ 7.4) saline (Azmitia and Gannon 1983), followed for 5 to 10 minutes at $5^{\circ} \mathrm{C}$ in the same solution with the addition of $0.003 \%$ hydrogen peroxide. Sections were counterstained with methyl green, dehydrated, and coverslipped with DPX mountant. Photographs were taken on a Leitz orthoplan microscope with planapo objectives, using T-Max 100 film.

\section{RESULTS}

The $5-\mathrm{HT}_{1 \mathrm{~A}}$ receptor antibody directed against the second EC loop (S1A-170-186) shows positive immunore-
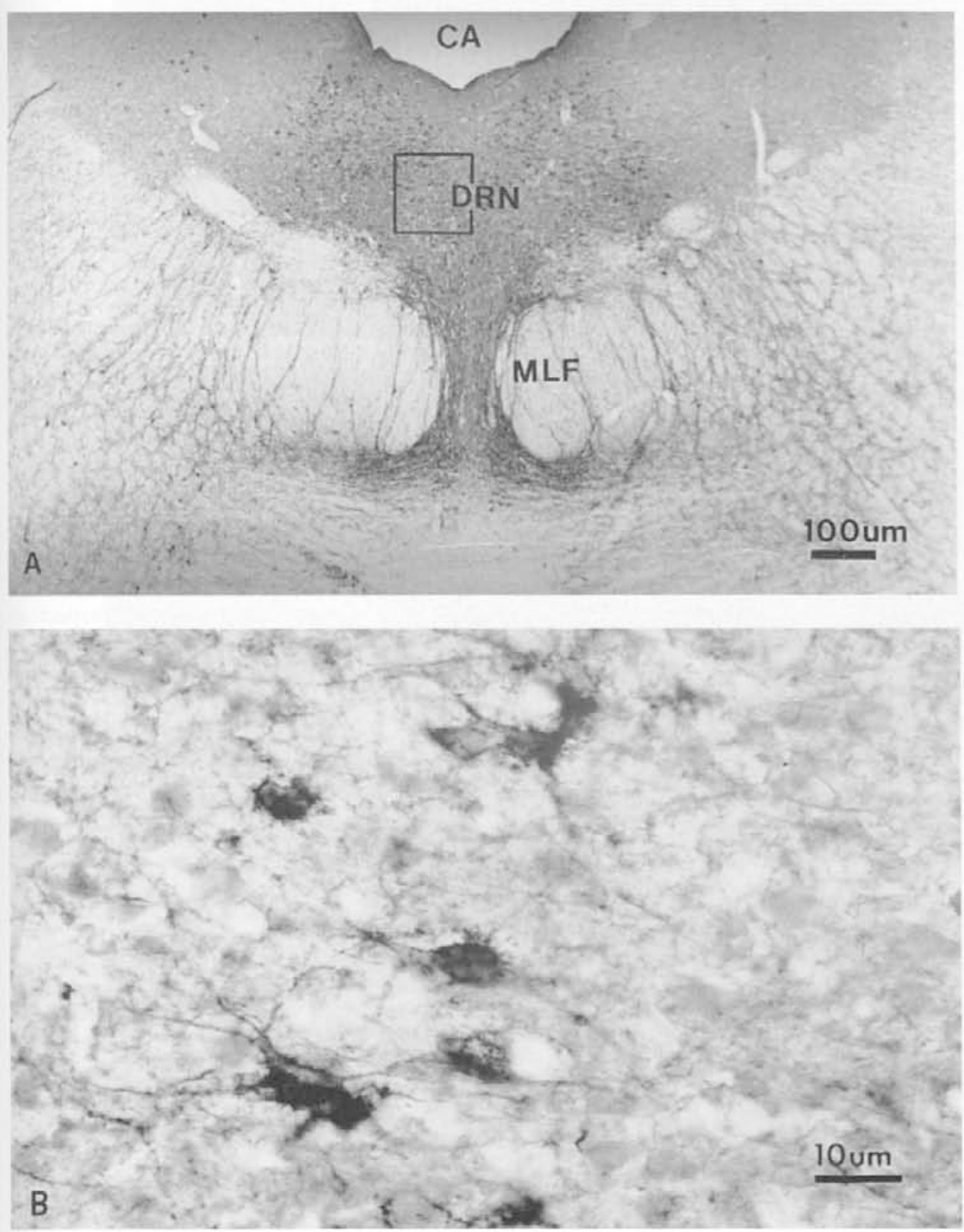

Figure 1. The dorsal raphe nucleus at its anterior border shown in coronal section. (A) Low magnification picture showing $5-\mathrm{HT}_{1 \mathrm{~A}}$ immunolabeled neurons of the dorsal raphe nucleus (DRN) bilaterally situated just off the midline below the cerebral aqueduct (CA) and above the medial longitudinal fasciculus (MLF). (B) High magnification photograph showing $5-\mathrm{HT}_{1 \mathrm{~A}}$ immunolabeled neurons marked by the box in (A). The soma and dendritic processes are heavily labeled; the label extends into dendritic spines. In addition, small pericellular glial cells and their processes are seen around the labeled neurons. 
activity throughout the primate brain with distinct regional and cellular patterns of localization. The cell types labeled included selected neurons, astrocytes, ependymal cells, and tanocytes. Two distinct patterns of neuronal labeling were present. We observed (1) a somatodendritic pattern in the midbrain and medullary raphe nuclei, locus coeruleus nucleus, and large reticular neurons in the pons, and (2) an axon-hillock pattern present on cortical and hippocampal pyramidal neurons and brainstem motoneurons. In addition, astrocytes, radial glia, ependymal, and endothelial cells showed a diffuse labeling pattern in both the cell body and processes.

\section{Somatodendritic Pattern}

Numerous multipolar neurons in the dorsal raphe nucleus, central superior nucleus and the medullary raphe nuclei are labeled throughout their soma, proximal dendrites, and fine branches and spines (Figure 1A,B). 5- $\mathrm{HT}_{1} \mathrm{~A}$ receptor immunoreactivity appears as dense punctate label in the soma and dendrites. This pattern is also present on many large neurons in the nucleus locus coeruleus (LCN) (Figure 4A). Although most raphe and $\mathrm{LCN}$ neurons show evidence of $5-\mathrm{HT}_{1 \mathrm{~A}}$ receptor immunoreactivity, labeling intensity varies from neuron to neuron in the adult monkey brain. Similarly, a general
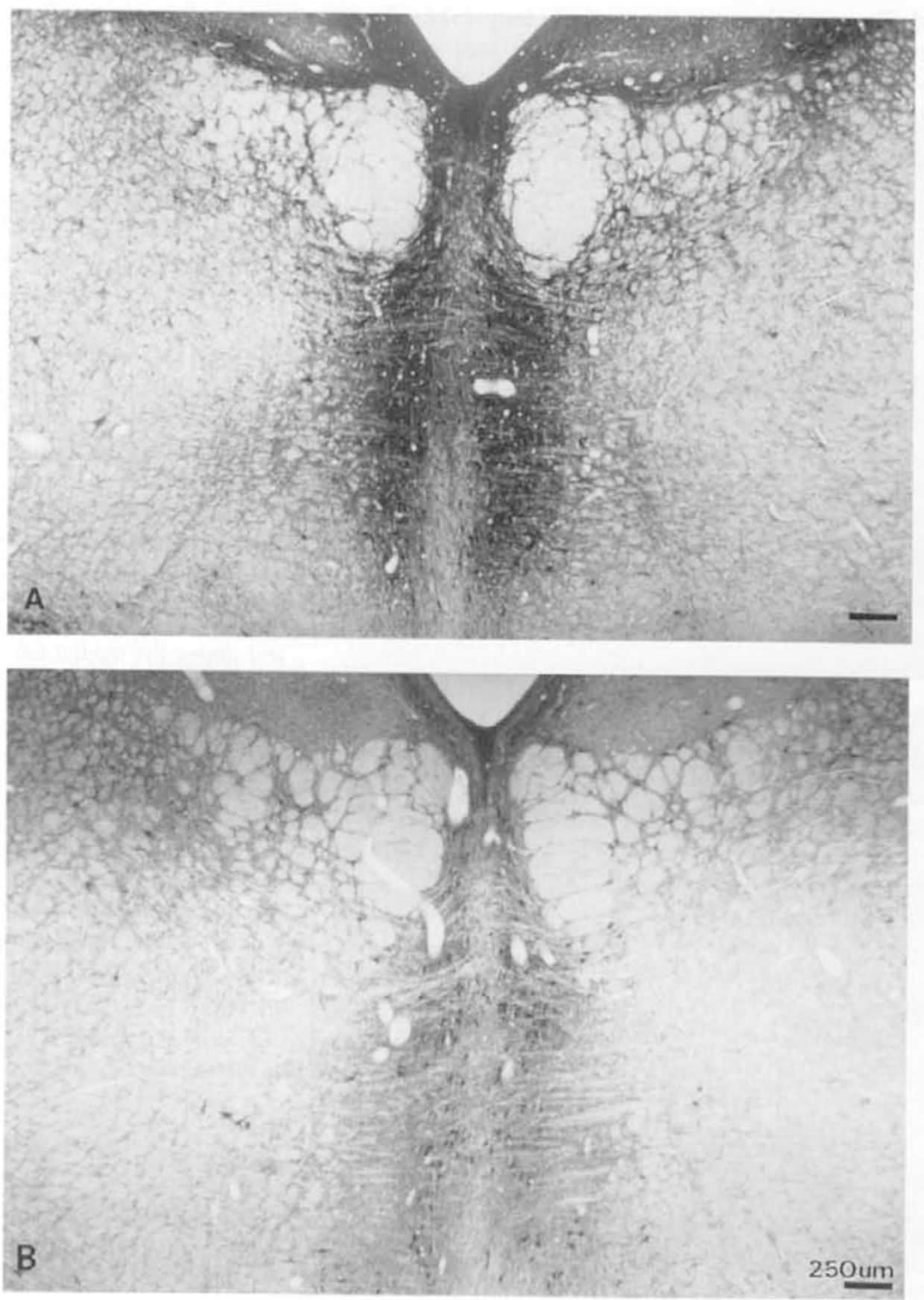

Figure 2. These photomicrographs show neighboring midbrain sections through the median raphe nucleus stained for (A) 5-HT immunoreactivity (IR) and (B) $5-\mathrm{HT}_{1 \mathrm{~A}}-\mathrm{IR}$. In (A) 5-HT-IR neurons and fibers can be seen at the caudal end of the median raphe nucleus where it merges with the interfascicular aspect of the dorsal raphe nucleus. In (B), an adjacent section to that shown in (A) shows cellular $5-\mathrm{HT}_{1 \mathrm{~A}}-\mathrm{IR}$. The distribution pattern of the immunoreactivity for both antibodies indicates hat the same cell population is being labeled. 

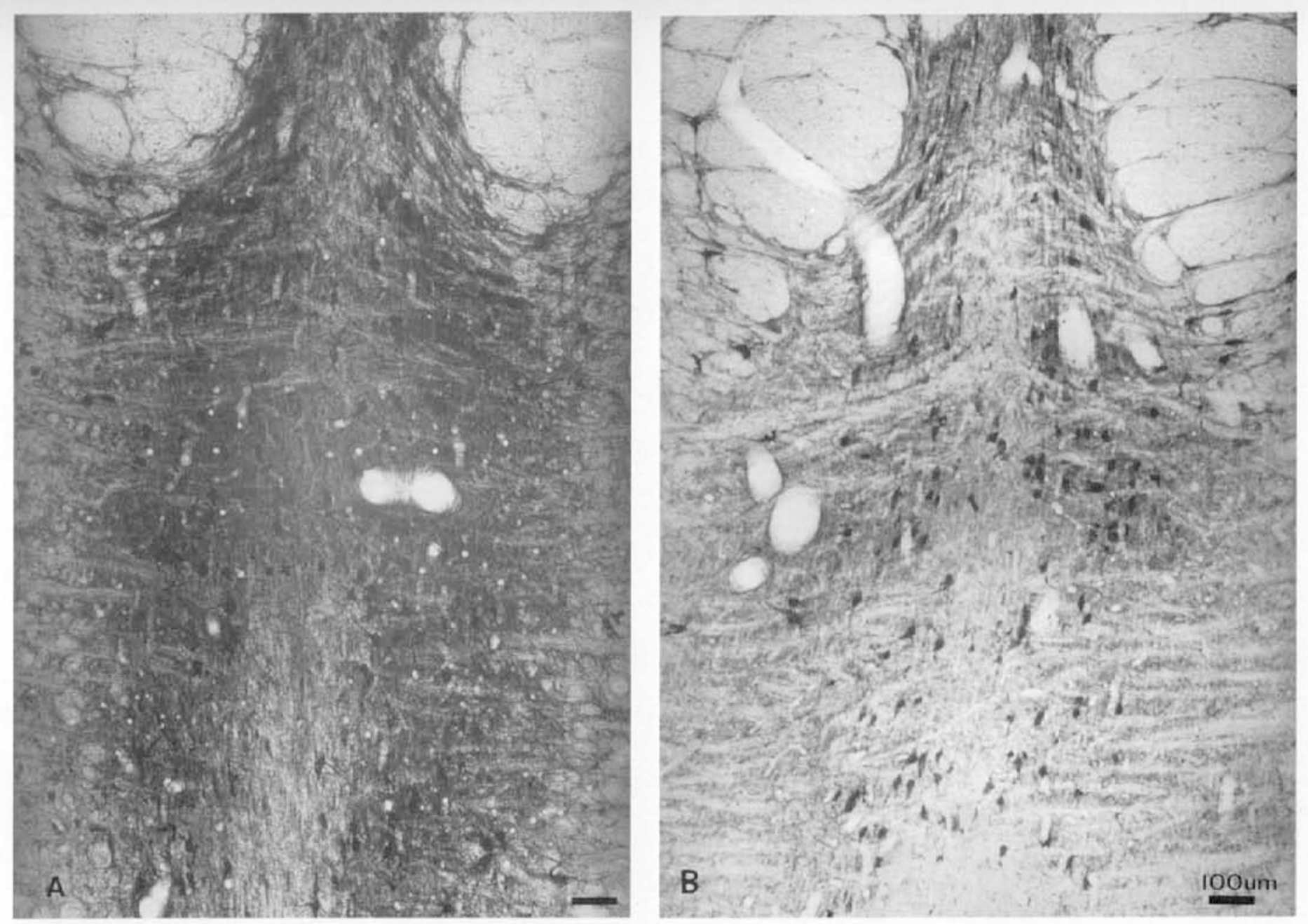

Figure 3. These photomicrographs are a higher magnification from the sections shown in Figure 2. (A) 5-HT-IR neurons; (B) 5-HT $1 \mathrm{~A}$ receptor-IR neurons in the median raphe nucleus. the size, shape, and general distribution of the immunoreactive neurons are similar in these adjacent sections. 

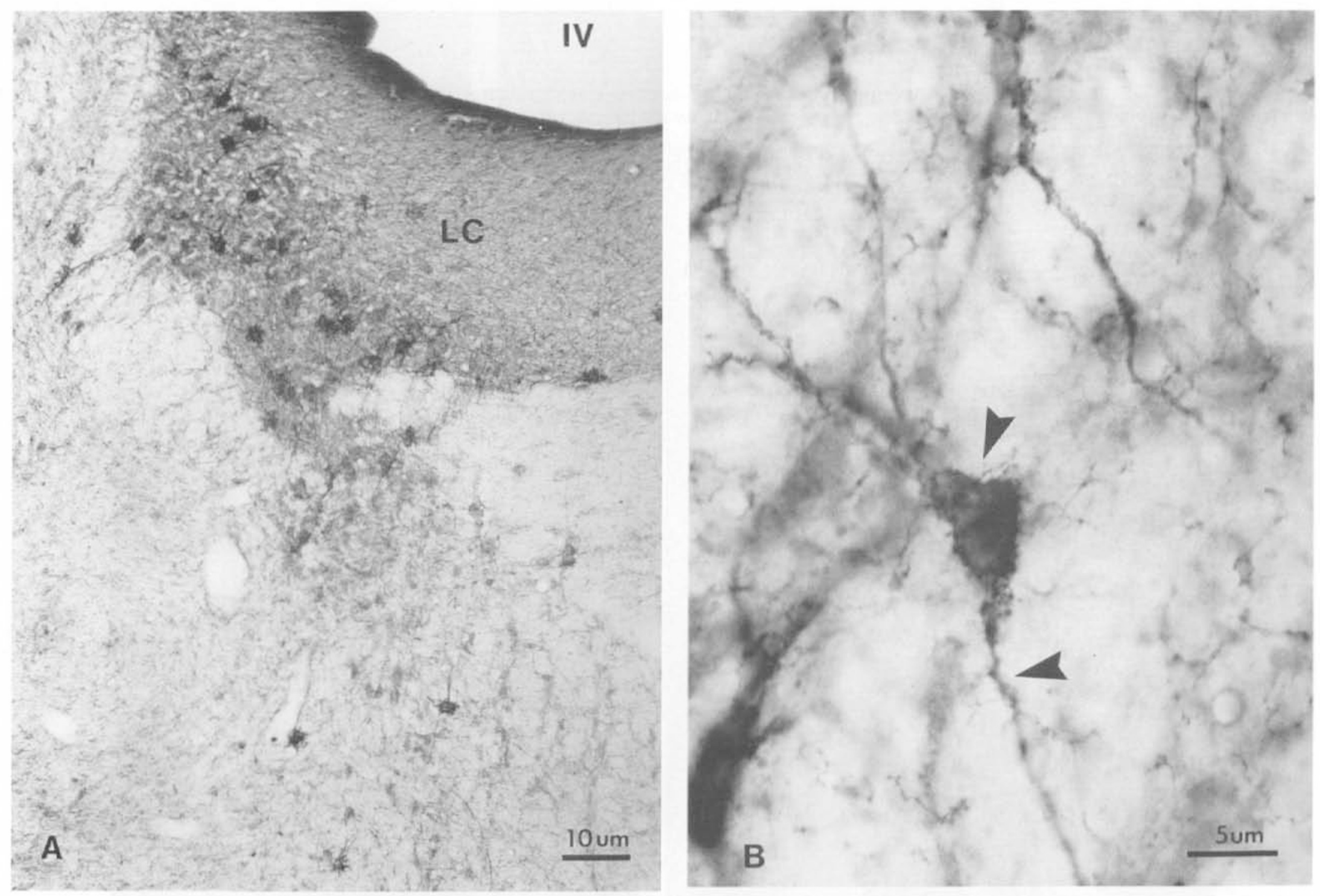

Figure 4. (A) The locus coeruleus nucleus (LC) and subcoeruleus are shown in coronal section below and lateral to the IV ventricle. The pattern of 5-HT $1 \mathrm{~A}$ receptor-IR is similar to that seen in the dorsal raphe nucleus (Figure 1). (B) High magnification (oil immersion) of large mesopontine reticular neurons, presumably containing acetylcholine. The somatodendritic $5-\mathrm{HT}_{1 \mathrm{~A}}$ labeling pattern is also comparable to that seen in the dorsal raphe nucleus. 

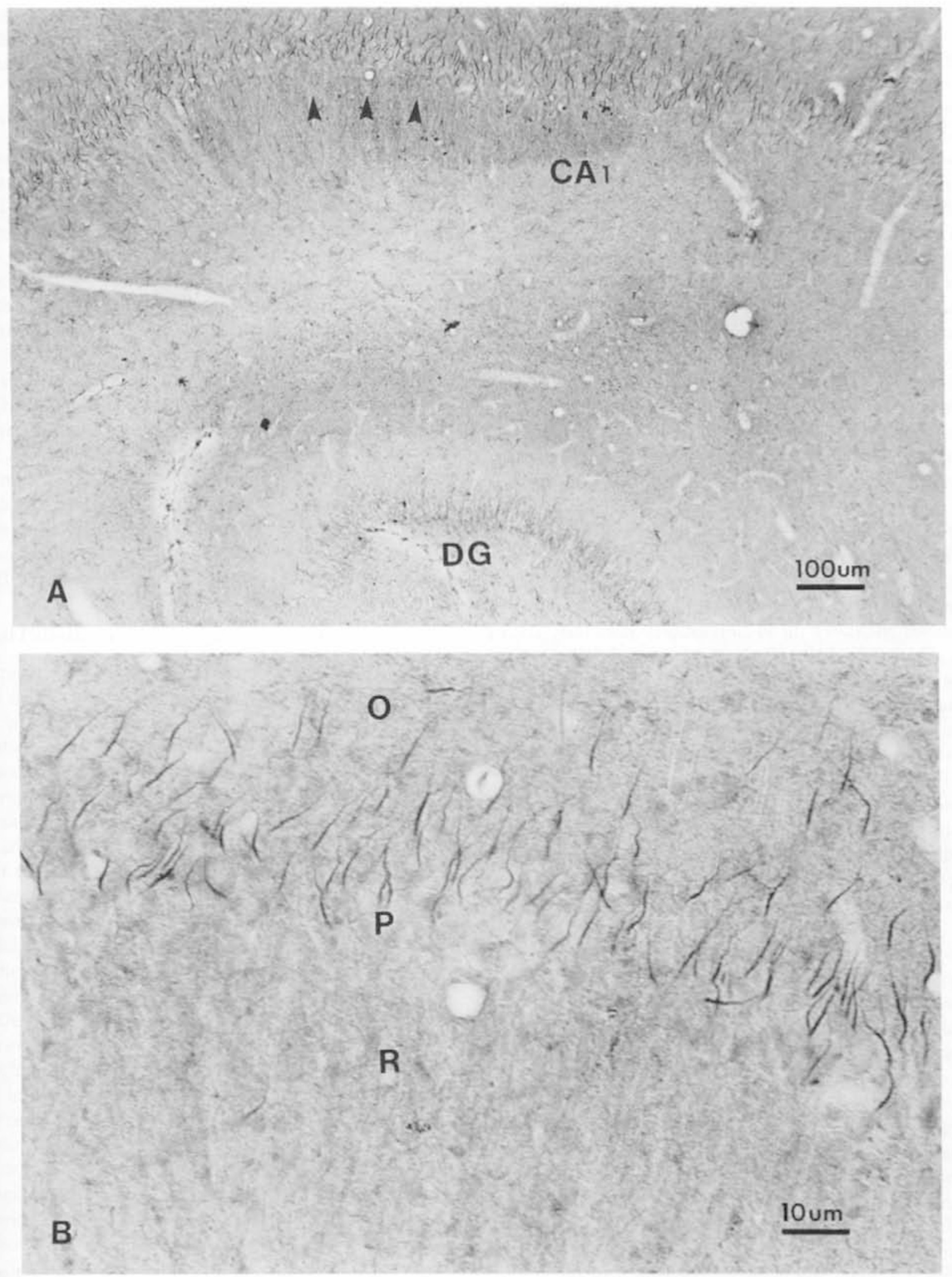

Figure 5. (A) The hippocampus with the Cornu Ammonus (CA) and dentate gyrus (DG) is shown in coronal section. Label is concentrated in pyramidal and granule cell layers. (B) Higher magnification photograph of the CA-1 subfield (marked by arrows in $\mathrm{A}$ ), illustrating the heavy $5-\mathrm{HT}_{1 \mathrm{~A}}$ immunolabeling of the initial axonal segment as they extend from the pyramidal cells $(\mathrm{P})$ into the stratum oriens $(\mathrm{O})$. The primary dendrites in the stratum radiatum $(\mathrm{R})$ are weakly labeled in comparison to the initial axon segment. Numerous labeled glial cells can be seen in the stratum radiatum. 

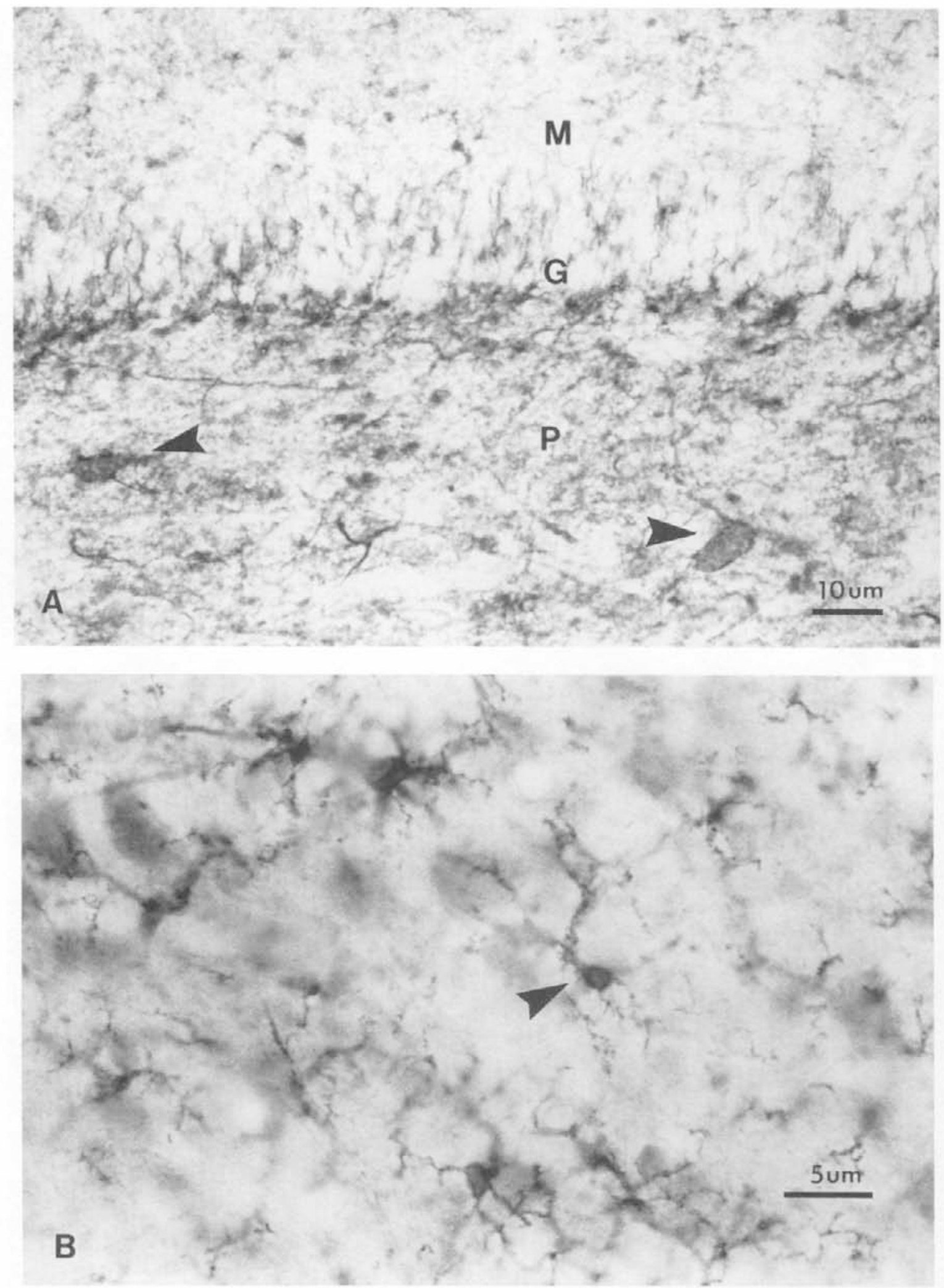

Figure 6. 5- $\mathrm{HT}_{1 \mathrm{~A}}$ receptor immunoreactivity on glial cells can be seen in (A) forebrain and (B) brainstem coronal sections. (A) High magnification photomicrograph of 5- $\mathrm{HT}_{1 \mathrm{~A}}$ immunostaining of radial glial cells in the dentate gyrus. The cell bodies are concentrated in the subgranular zone located immediately below the granular cell layer $(\mathrm{G})$. $\mathrm{The}^{5}-\mathrm{HT}_{1 \mathrm{~A}}$ immunolabeled processes of these cells extends through the granular cell layer. The granule neurons are weakly labeled. Labeled glial cells can also be seen in the molecular (M) and polymorphic (P) layers. A large interneuron in the polymorphic layer (arrow) has somadendritic $5-\mathrm{HT}_{1 \mathrm{~A}}$ immunolabeling similar to that pictured in Figures 1 and 4. 
somatodendritic pattern is present in scattered large multipolar neurons in the pontine reticular formation (Figure 4B).

\section{Axon-Hillock Pattern}

Pyramidal neurons in the Cornu Ammonus of the hippocampus (CA1-4) show very dense staining with the $5-\mathrm{HT}_{1 \mathrm{~A}}$ receptor antibody in the initial segment of the axon as it extended into the oriens layer (Figure 5B). This region appears to correspond to the axon hillock. Labeling of the cytoplasm and dendrites is weak, except for the area of perikaryon from which the axon emerges. Pyramidal neurons in cortical layers III and V also show this $5-\mathrm{HT}_{1 \mathrm{~A}}$ receptor immunoreactivity in the axon hillock (Figure 5A).

The motoneurons of the brainstem and spinal cord show $5-\mathrm{HT}_{1 \mathrm{~A}}$ receptor-IR concentrated in the axon hillock. A single tapering process emerging from individual motoneurons is observed in the oculomotor and hypoglossal cranial nerve motor nuclei, and in the ventral horn spinal motoneurons. The labeling of the cytoplasm is weak in comparison to the very dense localization of $5-\mathrm{HT}_{1 \mathrm{~A}}$ receptor-IR on the initial segment of the axon.

\section{Glial Pattern}

Astrocytes in the white matter of the corpus callosum and in the brainstem are immunoreactive throughout the whole cell. Radial glial cells in the hippocampal dentate gyrus are also labeled by the $5-\mathrm{HT}_{1 \mathrm{~A}}$ receptor antibody (Figure 6A). Furthermore, labeled glial cells (pericellular oligodendroglia cells) are present in the dorsal raphe nuclei and in the locus coeruleus (Figures $1 \mathrm{~A}$ and $4 \mathrm{~A}$ ). These labeled small cells are located adjacent to the large labeled neurons and send fine processes that appear to encircle the neuronal soma and primary dendrites. 5 - $\mathrm{HT}_{1 \mathrm{~A}}$ receptor immunoreactive pericellular glial cells are occasionally found near cerebral cortical pyramidal neurons, which are positively labeled with this receptor antibody.

Other cells types also appear to be immunoreactive. For example, scattered cells with the morphology of microglial cells in the pontine nuclei show $5-\mathrm{HT}_{1 \mathrm{~A}}$ receptor immunoreactivity. Occasional endothelial cells in the cerebral cortex and brainstem also show $5-\mathrm{HT}_{1 \mathrm{~A}}$ receptor-IR. Finally, the ependymal cells, which line the ventricular system where the supraependymal serotonergic fiber traverse, and tanocytes, which are modified ependymal cells that project within the median eminence, show intense $5-\mathrm{HT}_{1 \mathrm{~A}}$ receptor-IR.

\section{DISCUSSION}

The results of our anatomic studies with a specific antipeptide antibody (S1A-170) recognizing the second EC loop of the $5-\mathrm{HT}_{1 \mathrm{~A}}$ receptor, shows a pattern of $5-\mathrm{HT}_{1 \mathrm{~A}}$ receptor-IR much more diverse than previously revealed by radioautographic studies after ligand binding. The anatomic distribution of label is in general agreement with the diverse projections of 5-HT fibers in both the monkey and human brain (Azmitia and Gannon 1983), with the distribution seen with antibodies against the third IC loop (Raymond et al. 1989), with the binding of ${ }^{3} \mathrm{H}-8-\mathrm{OH}-\mathrm{DPAT}$ (Palacios et al. 1990), and the in situ localization of the 5- $\mathrm{HT}_{1 \mathrm{~A}}$ mRNA (Chalmers and Watson 1991; Miquel et al. 1992). The cellular labeling pattern is different within distinct neuronal populations. Specific immunolabeling with our $5-\mathrm{HT}_{1 \mathrm{~A}}$ receptor antibody (S1A-170) also occurs in nonneuronal cells.

Previous studies have demonstrated that $5-\mathrm{HT}_{1 \mathrm{~A}}$ receptor-IR is localized in rat neurons and glial cells. Somatodendritic autoreceptors are described in perikaryal and dendritic membranes of the rat midbrain raphe nuclei (Sotelo et al. 1990). In addition, we have shown the somatodendritic labeling, in monkey, of interneurons in the hilus of the dentate gyrus (Azmitia et al. 1992) and the discrete axon hillock labeling in motoneurons of the spinal cord, as well as on afferent sensory fibers of the dorsal horns (Kheck et al. 1995). During development, $5-\mathrm{HT}_{1 \mathrm{~A}}$ receptor protein and message are localized to radial glial cells (Hellendall et al. 1992). In the adult brain, cells labeled with both the (S1A-170) $5-\mathrm{HT}_{1 \mathrm{~A}}$ receptor antibody and glial fibrillary acidic protein were seen in rat hippocampus, septum, cortex, and caudate (Whitaker-Azmitia et al. 1992). The antipeptide antibody raised against the third IC loop by Raymond et al. (1989) also labels immature (Lauder and Liu 1994) and mature astrocytes (unpublished observations). This report is the first time all cellular localization patterns have been visualized in the primate brain. The antibody used in this study specifically recognizes a unique peptide sequence of the $5-\mathrm{HT}_{1 \mathrm{~A}}$ receptor protein that corresponds to part of the second extracellular loop, and comprises part of the ligand binding site (Azmitia et al. 1992). Although the number of cells labeled is diverse, two main cellular localization patterns were commonly observed with our receptor antibody. The general labeling of the cell body with its main processes is seen in brainstem nuclei that contain predominately serotonergic and noradrenergic neurons (somatodendritic pattern), in large multipolar neurons in the dentate gyrus hilus, and in pontine medullary reticular formation (whole-cell pattern). The dense labeling of the initial segment of axons (axon-hillock pattern) is seen in motoneurons throughout the brainstem and spinal cord and in the pyramidal neurons in cortex and hippocampus. At the electron microscopic level, the label was seen on the plasma membrane and cytoskeletal elements (Azmitia et al. 1992).

What might be the functional significance of the general staining pattern of neurons? The general distribu- 
tion of the $5-\mathrm{HT}_{1 \mathrm{~A}}$ receptor protein in the cell body and dendrites of a neuron appears to correspond to the pronounced hyperpolarization after treatment with a $5-\mathrm{HT}_{1 \mathrm{~A}}$ receptor agonist (Aghajanian and Lakoski 1984; Williams et al. 1988). A number of 5- $\mathrm{HT}_{1 \mathrm{~A}}$ agonists have full agonist properties on raphe neurons (see Zifa and Fillion 1992), locus coeruleus (Charlety et al. 1991), mesopontine cholinergic neurons controlling REM sleep (Leonard and Llinas, 1994), and GABA interneurons in the dentate gyrus controlling granule neuronal excitability (Segal 1990). Thus, the somatodendritic pattern correlates with a pronounced hyperpolarization mediated event. The second pattern of staining, with heavy labeling of the initial axonal segment, may correspond to a different function of the receptor. This neuronal "axon-hillock" pattern, seen in the pyramidal cells of the cerebral cortex (layers III and V), Cornu Ammonus (CA), and subiculum of the hippocampus, showed the $5-\mathrm{HT}_{1 \mathrm{~A}}$ receptor mainly concentrated in the axon initial segment, and in only a portion of the perikaryon adjacent to the axon hillock. It has previously been suggested that cortical pyramidal neurons contain a significant number of 5- $\mathrm{HT}_{1 \mathrm{~A}}$ receptors (Francis et al. 1992). The $5-\mathrm{HT}_{1 \mathrm{~A}}$ receptor- $\mathrm{IR}$ of the axon hillock has also been reported in the monkey spinal cord (Kheck et al. 1995). The reason for the localized concentration of $5-\mathrm{HT}_{1 \mathrm{~A}}$ receptor-IR with the $\mathrm{S} 1 \mathrm{~A}-170$ antipeptide antibody is certainly due to the specific epitope selected (aa 170-186). Other antipeptide 5- $\mathrm{HT}_{1 \mathrm{~A}}$ antibodies directed against the $\mathrm{N}$-terminus and the 3rd cytoplasmic loop, which labeled the same protein band in SDS-gel electrophoresis studies, did not show the intense axon hillock immunoreactivity; however, they do label the soma of the same cell populations. This differential labeling with the 2nd EC antibody may be due to region specific masking of the epitope, membrane anchoring or side chain modification.

The localization of the $5-\mathrm{HT}_{1 \mathrm{~A}}$ receptor in the axon hillock uniquely positions serotonin to modulate the formation of an action potential. The hippocampus CA pyramidal neurons showed very dense labeling of the initial axonal segment in contrast to sparse $5-\mathrm{HT}_{1 \mathrm{~A}}$ receptor labeling in the soma or dendrites. The axon-hillock pattern also predominates in cortical pyramidal neurons, and in brainstem and spinal cord motoneurons. All these areas are known to receive a substantial serotonergic innervation in the primate (Azmitia and Gannon 1986). It has been noted that in studies of cortical neurons, $5-\mathrm{HT}_{1 \mathrm{~A}}$ agonists may block the firing of a pyramidal neuron without producing a significant hyperpolarization (G. Aghajanian, personal communication). A similar observation was made in hippocampal slices when low concentrations of 5-HT were studied (M. Segal, personal communication). These neurons do show somatodendritic labeling with another antibody (third IC) so the effects of $5-\mathrm{HT}$ on these neurons may be a composite of these two locations. However, the heavy intensity of labeling with the second EC antibody emphasizes the potential importance of the axon hillock in $5-\mathrm{HT}_{1 \mathrm{~A}}$ receptor function.

Thus, the $5-\mathrm{HT}_{1 \mathrm{~A}}$ receptor is the first receptor protein immunohistochemically shown to be localized to the axon hillock. The initial axonal segments (like the nodes of Ranvier) are characterized by an electron dense material beneath the plasma membrane and a layer of granular material outside the axolemma (Peters et al. 1990). The axon hillock can receive synaptic contacts, and at these sites the undercoating and the granular material is absent. Normally, the axon-hillock zone is not opposed to either neuronal (e.g., synapses) or glial (e.g., myelin) elements, but is surrounded by extracellular fluid (Matsumura and Kohno 1991). This part of the axon has a very high density of voltage-dependent sodium channels (Angelides et al. 1988). Thus, 5-HT could exert a nonsynaptically mediated inhibition of the initiation of the action potential. Recent studies indicate that removal of hippocampal 5-HT by 5,7-DHT results in an increased $5-\mathrm{HT}_{1 \mathrm{~A}}$ immunoreactivity in the axon hillock of CA pyramidal neurons (Patel et al. 1995). This evidence of receptor plasticity occurs at a key site of neuronal excitation.

Both the general and localized $5-\mathrm{HT}_{1 \mathrm{~A}}$ receptor labeling pattern can be observed within a single region of the brain. In the hippocampus, the CA neurons show a predominately axon hillock pattern in the pyramidal neurons, but the interneurons of the dentate gyrus hilus show a somatodendritic (general) pattern. This may be consistent with the observation that in the hippocampus, $8-\mathrm{OH}$ DPAT produces a greater reduction in the amplitude population spikes in the CA1 region than in the dentate gyrus (Klancnik et al. 1991).

Finally, in addition to neurons, glial cells display a whole cell distribution of the $5-\mathrm{HT}_{1 \mathrm{~A}}$ receptor antibody. This is seen in the soma and processes of some astrocytes located in white matter, in the radial glial of the hippocampal dentate gyrus, and in tanocytes and ependymal cells. In a previous study, select astrocytes labeled with an antibody against GFAP also showed labeling with our $5-\mathrm{HT}_{1 \mathrm{~A}}$ antipeptide antibody in rat hippocampus, septum, and entorhinal cortex but not caudate (Whitaker-Azmitia et al. 1992). An antibody raised against the third IC loop (Raymond et al. 1989, 1993) has also been shown to label astrocytes in the adult primate brain (unpublished observation). In the developing rat brain and in tissue culture, identified radial glial cells and astrocytes were demonstrated to contain both the protein and message for the $5-\mathrm{HT}_{1 \mathrm{~A}}$ receptor (Hellendall et al. 1992; Lauder and Liu 1994; Hirst et al. 1994). The actions of $5-\mathrm{HT}_{1 \mathrm{~A}}$ agonists on glial cells may subserve trophic effects of neurons.

It can be speculated that the diverse localization for the $5-\mathrm{HT}_{1 \mathrm{~A}}$ receptor on neurons, astrocytes, and other 
nonneuronal cells may have clinical implications: (1) The initial segments of axons would be an ideal target for $5-\mathrm{HT}_{1 \mathrm{~A}}$ agonist to regulate cell discharge without disruption of general cellular metabolism due to hyperpolarization. These sites may be more resistant to downregulation and remain active after chronic treatment with an agonist. (2) The somatodendritic location would produce a generalized reduction of neuronal activity coupled with a significant depolarization of the cell body. Hyperpolarization after a $5-\mathrm{HT}_{1 \mathrm{~A}}$ agonist has been reported for a number of "global" functioning neurons, including the serotonergic, noradrenergic, cholinergic, and GABAergic neurons. Receptors at these sites may be downregulated by $5 \mathrm{HT}_{1 \mathrm{~A}}$ agonists, and these systems play important roles in affective states. (3) Finally, activation of the 5- $\mathrm{HT}_{1 \mathrm{~A}}$ receptor on astrocytes would produce a general response throughout the cell, and again the receptors here would be expected to be more plastic. During development, astrocytic $5-\mathrm{HT}_{1 \mathrm{~A}}$ receptors can regulate the release of neuronotrophic factors involved in normal brain maturation (see Akbari et al. 1994; Whitaker-Azmitia et al. 1990). Whether fiber sprouting in the adult brain can be modified by $5-\mathrm{HT}_{1 \mathrm{~A}}$ drugs and prove effective in brain plasticity after injury or in mental diseases remains to be established. Future work will determine whether these various receptor cellular sites can be preferentially manipulated, either by selected agonist or route, and the duration of administration.

\section{ACKNOWLEDGMENTS}

This work was supported in part by NIA grant PO1 AG10208; the Department of Biology, New York University; and the Department of Otolaryngology, Mount Sinai School of Medicine, New York. We thank Dr. William J. Doyle, Director of Otolarngology Research Labs, Children's Hospital of Pittsburgh, for providing us with the monkey brain tissues, which were from animals used in a project funded by NIH grant DC 01260.

\section{REFERENCES}

Aghajanian GK, Lakoski JM (1984): Hyperpolarization of serotonergic neurons by serotonin and LSD: Studies in brain slices showing increased $\mathrm{K}^{+}$conductance. Brain Res 305:181-185

Akbari HM, Whitaker-Azmitia PM, Azmitia EC (1992): In Utero exposure to cocaine results in decreased availability of the tropic factor S-100ß: A possible mechanism for cocaine-induced microcephaly. Neurosci Lett 170:141144

Albert PR, Zhou Q-Y, Van Tol HHM, Bunzow JR, Civelli O (1990): Cloning, functional expression, and mRNA tis- sue distribution of the rat 5-hydroxytryptamine 1 A receptor gene. J Biol Chem 265:5828-5832

Angelides K, Elmer LW, Loftus D, Elson E (1988): Distribution and lateral mobility of voltage-dependent sodium channels in neurons. J Cell Biol 106:1911-1925

Anthony TE, Kheck NM, Albert PR, Whitaker-Azmitia PM, Azmitia EC (1995): Molecular characterization of antipeptide antibodies against rat brain 5-HT-1A receptor. Soc Neurosci Abstr 21:1852

Aoki C, Pickel VM (1990): Ultrastructural immunocytochemical evidence or presynaptic localization of $\beta$-adrenergic receptors in the striatum and cerebral cortex of rat brain. Ann NY Acad Sci 604:582-585

Aoki C (1992): Adrenergic receptors: Astrocytic localization in the adult visual cortex and their relation to catecholamine axon terminals as revealed by electron microscopic immunocytochemistry. J Neurosci 12:781-792

Aoki C, Joh TH, Pickel VM (1987): Ultrastructural localization of $\beta$-adrenergic receptorlike immunoreactivity in the cortex and neostriatum of rat brain. Brain Res 437: 264-282

Azmitia EC, Yu I, Akbari HM, Kheck N, Whitaker-Azmitia PM, Marshak DR (1992): Antipeptide antibodies against the $5-\mathrm{HT}_{1 \mathrm{~A}}$ receptor. J Chemical Neuroanatomy 5:289298

Azmitia EC, Gannon PJ (1986): Anatomy of the serotonergic system in the primate and subprimate brain. In Fahn S, Marsden CD, Van Woert M (eds), Myoclonus. Adv Neurol 43:407-468

Bar-Peled O, Gross-Isseroff R, Ben-Hur H, Hoskins I, Groner Y, Biegon A (1991): Fetal human brain exhibits a prenatal peak in the density of serotonin $5-\mathrm{HT}_{1 \mathrm{~A}}$ receptors. Neurosci Lett 127:173-176

Chalmers DT, Watson SJ (1991): Comparative anatomic distribution of $5-\mathrm{HT}_{1 \mathrm{~A}}$ receptor $\mathrm{mRNA}$ and $5-\mathrm{HT}_{1 \mathrm{~A}}$ binding in rat brain-a combined in situ hybridization/in vitro receptor autoradiography study. Brain Res 561:51-60

Charlety PJ, Aston-Jones G, Akaoka H, Buda M, and Chouvet $\mathrm{G}$ (1991): Participation des répteurs $5-\mathrm{HT}_{1 \mathrm{~A}}$ dans la diminution par la sérotonine de l'excitation des neurones du locus coeruleus évoquée par la glutamate. C R Acad Sci Paris 312:421-426

Chou P, Fasman GD (1978): Prediction of the secondary structure of proteins from their amino acid sequence. Adv Enzymology 47:45-147

Francis PT, Pangalos MN, Pearson RCA, Middlemiss DN, Stratmann GC, Bowen DM (1992): 5-Hydroxytryptamine $_{1 \mathrm{~A}}$ but not 5-hydroxytryptamine 2 receptors are enriched on neocortical pyramidal neurones destroyed by intrastriatal volkensin. J Pharmacol Exp Ther 261: $1273-1281$

Hellendall RP, Schambra U, Liu J, Breese GR, Millhorn DE, Lauder JM (1992): Detection of serotonin receptor transcripts in the developing nervous system. J Chem Neuroanatomy 5:299-310

Hirst WD, Rattray AN, Price GW, Wilkin GP (1994): Expression of $5-\mathrm{HT}_{1 \mathrm{~A}}, 5-\mathrm{HT}_{2 \mathrm{~A}}$, and $5-\mathrm{HT}_{2} \mathrm{C}$ receptors on astrocytes. Soc Neurosci Abstr 20:1547

Hopp TP, Woods R (1981): Prediction of protein antigenic determinants from amino acid sequences. Proc Natl Acad Sci USA 8:3824-3828 
Kheck NM, Gannon PJ, Azmitia EC (1995): 5- $\mathrm{HT}_{1 \mathrm{~A}}$ receptor localization on the axon hillock of cervical spinal motoneurons in primates. J Comp Neurol 355:211-220

Klancnik JM, Obenaus A, Phillips AG, Baimbridge KG (1991): The effects of sertonergic compounds on evoked responses in the dentate gyrus and $\mathrm{CA} 1$ region of the hippocampal formation of the rat. Neuropharmacology 30:1201-1209

Kobilka BK, Frielle T, Collins S, Yang-Feng T, Kobilka TS, Francke U, Lefkowitz RJ, Caron MG (1987): An intronless gene encoding a potential member of the family of receptors coupled to guanine nucleotide regulatory proteins. Nature 329:75-79

Lauder JM, Liu J (1994): Glial heterogeneity and developing neurotransmitter systems. Persp Dev Biol 2:239-250

Leonard CS, Llinás R (1994): Serotonergic and cholinergic inhibition of mesopontine cholinergic neurons controlling REM sleep: An in vitro electrophysiologic study. Neuroscience 59:309-330

Matsumura A, Kohno K (1991): Microtubule bundles in fish cerebellar Purkinje cells. Anat Embryol 183:105-110

Miquel M-C, Doucet E, Boni C, El Mestikawy S, Matthiessen L, Daval G, Verge D, Hamon M (1992): Central serotonin 1 A receptors: respective distributions of encoding $\mathrm{mRNA}$. receptor protein and binding sites by in situ hybridization histochemistry, radioimmunohistochemistry, and autoradiography mapping in the rat brain. Neurochem Int 19:453-465

Palacios JM, Waeber C, Hoyer D, Mengod G (1990): Distribution of serotonin receptors. Ann NY Acad Sci 600:36-52

Patel TD, Azmitia EC, Zhou FC (1995): Increased 5-HT 1 A receptor immunoreactivity in the rat hippocampus following 5,7-DHT lesions in the cingulum bundle and fornix-fimbria. Behav Brain Res (in press)

Peters A, Palay SL, Webster HF (1991): The Fine Structure of the Nervous System, ed 3. New York, Oxford University Press.
Raymond JR, Fargin A, Lohse MJ, Regan JW, Senogles SE, Lefkowitz RJ, Caron MG (1989): Identification of the ligand-binding subunit of the human 5-hydroxytryp. tamine $_{1 \mathrm{~A}}$ receptor with $\mathrm{N}$-(p-Azido- $\left[{ }^{125}\right]$ iodophenethyl) spiperone, a high affinity radioiodinated photoaffinity probe. Mol Pharmacol 36:15-21

Raymond JR, Kim J, Beach RE, Tisher CC (1993): Immunohistochemical mapping of cellular and subcellular distribution of $5-\mathrm{HT}_{1 \mathrm{~A}}$ receptors in rat and human kidneys. Am J Physiol 264:F9-F19

Segal M (1990): Serotonin attenuates a slow inhibitory postsynaptic potential in rat hippocampal neurons. Neuroscience 36:631-641

Sotelo C, Cholley B, El Mestikawy S, Gozlan H, Hamon M (1990): Direct immunocytochemical evidence for the existence of $5-\mathrm{HT}_{1 \mathrm{~A}}$ autoreceptor on serotonergic neurons in the midbrain raphe nuclei. Eur J Neurosci 2:1144-1154

Verdot L, Ferrer-di-Martino M, Bertin B, Strosberg AD, Hoebeke J (1994): Production of antibodies directed against the first and second extracellular loop of the human serotonin 5- $\mathrm{HT}_{1 \mathrm{~A}}$ receptor. Biochimie 76:165-170

Williams J, Colmers W, Pan Z (1988): Voltage- and ligand-activated inwardly rectifying currents in dorsal raphe neurons in vitro. J Neurosci 8:3499-3506

Whitaker-Azmitia PM, Clarke C, Azmitia EC (1992): 5- $\mathrm{HT}_{1}$ immunoreactivity in brain astrocytes co-localized with GFAP. Synapse 14:201-205

Whitaker-Azmitia PM, Murphy RB, Azmitia EC (1990): S-100 protein release from astrocytic glial cells by stimulation of $5-\mathrm{HT}_{1 \mathrm{~A}}$ receptors and regulates the development of serotonergic neurons. Brain Res 528:155-158

Whitaker-Azmitia PM, Peroutka SJ (1990): The Neuropharmacology of Serotonin, vol 600. New York, NY Academy of Science, pp 1-718

Zifa E, Fillion G (1992): 5-Hydroxytryptamine receptors. Pharmacol Rev 44:402-458 




